\title{
Osteochondroma at the distal radial metaphysis in a horse
}

\author{
N. Jansson
}

The Animal Hospital of Halland, Slöinge, Sweden

\begin{abstract}
Summary
The present report describes a case of osteochondroma formation at the left distal radial metaphysis in a 3-year-old warmblood stallion. The horse displayed the typical clinical and radiographic symptoms of this condition. The osteochondroma was subsequently removed surgically employing a medial incisional approach to the carpal canal sheath. Gross pathologic and histologic examination of the extirpated bony process confirmed the diagnosis of osteochondroma. Follow-up 4 months postoperatively revealed that the horse was no longer showing clinical symptoms referable to the original disease.
\end{abstract}

keywords: $\quad$ osteochondroma, surgery, extirpation, histology, horse

\begin{abstract}
Osteochondrom der distalen Radiusmetaphyse bei einem Pferd
Osteochondrome sind mit Knorpel bedeckte Knochenvorsprünge, die durch enchondrale Ossifikation wachsen. Nach Epiphysenfugenschluß sistiert das Wachstum. Da aber manche Pferde erst mit 5 Jahren klinisch auffällig werden, wird vermutet, daß das periostale Wachstum allmählich fortschreitet. Osteochondrome der distalen Radiusmetaphyse zählen zu den Ursachen des Karpaltunnelsyndroms. Differentialdiagnostisch kommen Tendinitis der Beugesehne, Tendosynovitis, Fraktur des Os accessorium und Desmitis des Ligamentum accessorium der oberflächlichen Beugesehne in Frage. Da nur eine Gliedmaße betroffen ist im Gegensatz zu hereditären multiplen Exostosen, ist davon auszugehen, daß die Erkrankung nicht vererbt wird. Es wird der Fall eines dreijährigen Hengstes vorgestellt, der seit drei Monaten vorne links lahm ging. Stallruhe brachte keine Besserung. Die klinische Untersuchung ergab eine Lahmheit vom Grad 2 von 5, Schwellung der Sehnenscheide des Karpaltunnels, Schmerzhaftigkeit bei Beugung des Karpalgelenks und bei tiefer Palpation caudomedial am Karpus. Auf der Röntgenaufnahme war eine $1 \mathrm{~cm}$ erhabene Knochenzubildung caudomedial an der distalen Radiusmetaphyse zu sehen. Es erfolgte eine operative Entfernung des Osteochondroms, das im Anschluß histologisch bestätigt werden konnte. Die Sehenscheide wurde freigelegt, punktiert, die Synovia untersucht (reduzierte Viskosität, $38 \mathrm{~g}$ Protein/L), eine $5 \mathrm{~cm}$ lange Inzision gesetzt, die Synovia abgesaugt, das Osteochondrom reseziert, ein Debridement des caudalen Radius durchgeführt, die Sehenscheide gespült, die Wunde verschlossen und ein Druckverband angelegt. Der postoperative Verlauf zeigte völliges Verschwinden der Symptome in einem Zeitraum von 4 Monaten. Eine weitere Möglichkeit der chirurgischen Behandlung stellt der arthroskopische Zugang dar. Hier liegen die Vorteile in geringerem Gewebstrauma und Infektionsrisiko, besserer Übersicht innerhalb der Sehnenscheide, günstigere kosmetische Ergebnisse und kürzeren Operations- und Rekonvaleszenzzeiten
\end{abstract}

Schlüsselwörter: Osteochondrom, Chirurgie, Entfernung des Osteochondroms, Histologie, Pferd

\section{Introduction}

Osteochondroma formation at the caudal aspect of the distal metaphysis of the radius is a relatively uncommon cause of lameness in the horse (Stahre and Tufvesson 1967; Lundvall and Jackson 1976; Stashak 1987; Held et al. 1988; Honnas 1992). An osteochondroma presents as a cartilage-covered bony protuberance, the growth of which takes place by endochondral ossification (Jubb et al. 1985). It has been stated that the growth of the osteochondroma is correlated with that of the distal physis of the radius, and that the growth ceases once physeal closure occurs (Jubb et al. 1985). The fact that, in some horses affected with distal radial osteochondromas, clinical symptoms first become evident after 5 years of age has lead to speculation that continued slow periosteal growth might occur after physeal closure (Honnas 1992). The cause of the condition is presently unknown, but is believed to be non-hereditary (Stashak 1987; Honnas 1992). Reported clinical symptoms include swelling of the common tendon sheath of the superfi- cial and deep digital flexor tendons (carpal canal sheath), pain on flexion of the carpus and deep palpation of the caudomedial aspect of the carpus, and varying degrees of lameness (Stashak 1987; Honnas 1992). As such, osteochondroma formation at the distal radial metaphysis is one of several causes of the so-called 'carpal canal syndrome' (Stashak 1987). Treatment of the condition is surgical and comprises either resection of the carpal flexor retinaculum on the caudomedial aspect of the carpus (Stashak 1987) or surgical extirpation of the osteochondroma from within the tendon sheath, using incisional or endoscopic approaches (Lundvall and Jackson 1976; Lee et al 1979; Held et al. 1988; Squire et al. 1992; Southwood et al. 1997). Surgical extirpation is the preferred technique in cases with larger osteochondromas, and resection of the carpal flexor retinaculum should be limited to cases with smaller rounded lesions (Stashak 1987). The present report describes the scribes the diagnosis and surgical treatment of a case of 
distal radial osteochondroma in a 3-year-old warmblood stallion.

\section{Case history}

A 3-year-old warmblood stallion was admitted to the Large Animal Hospital at the Royal Veterinary and Agricultural University of Copenhagen due to a left forelimb lameness. The lameness had first been observed 3 months prior to admission, and the initial treatment had consisted of stall rest. No improvement of the lameness was observed during the period of rest.

\section{Clinical and radiographic findings}

On admission, the horse was lame in the left forelimb grade 2 out of 5 . The carpal canal sheath was swollen and the horse resented attempts at carpal flexion. Deep palpation of the caudomedial aspect of the carpus also elicited a painful response. The horse was afebrile and showed no signs of systemic illness.

Radiographs of the left carpus were subsequently taken and these revealed an approximately $1 \mathrm{~cm}$ high bony protuberance located caudomedially at the distal metaphysis of the radius (Fig. 1).

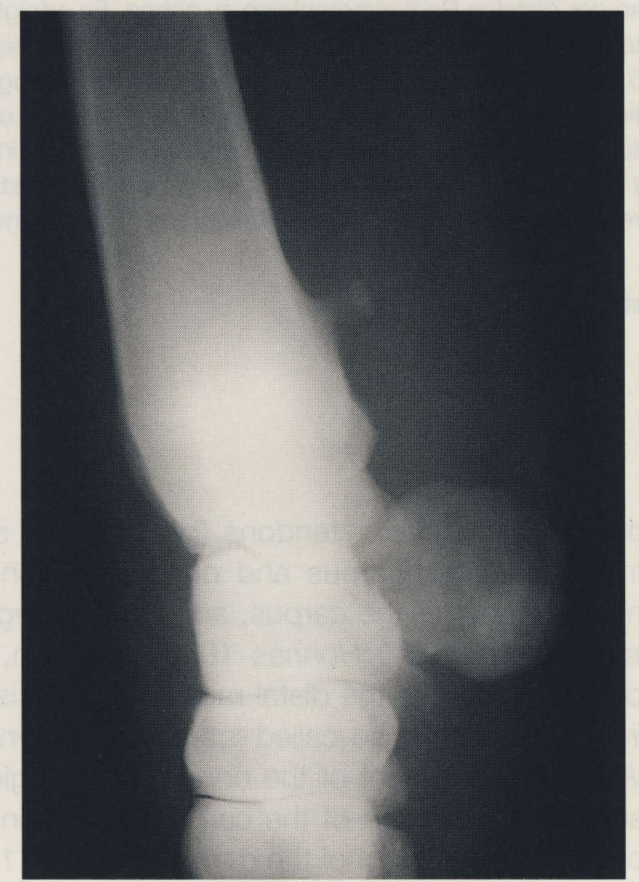

Fig. 1: Radiograph of the left carpus of a 3-year-old warmblood stallion affected with osteochondroma formation at the distal radial metaphysis. The radiodense protuberance originating at caudal aspect of the distal radius is easily identified.

Röntgenaufnahme des linken Carpus eines 3 Jahre alten warmblütigen Hengstes mit einer Osteochondrom-Bildung an der distalen Radiusmetaphyse. Die von der kaudalen Seite des distalen Radius ausgehende Protuberanz ist röntgenologisch gut sichtbar.
Based on the clinical and radiographic findings, a tentative diagnosis of osteochondroma formation at the left distal radial metaphysis was made. Due to the size and shape of the presumed osteochondroma, it was decided that surgical removal would be the most effective therapeutic option.

\section{Surgery}

The horse was anaesthetized by standard techniques and maintained on an oxygen/halothane mixture administered in a semi-closed system. Approximately 20 minutes before making the skin incision, $6 \mathrm{~g}$ of ampicillin (Anhypen; Yamanouchi, The Netherlands) was administered intravenously as a prophylactic antibiotic.

The horse was positioned in left lateral recumbency and the medial aspect of the left forearm and carpus was prepared for surgery. A $6 \mathrm{~cm}$ skin incision was made cranial and parallel to the cephalic vein extending distally from the level of the distalmost aspect of the chestnut. The incision was continued through the antebrachial fascia, thus exposing the flexor carpi radialis tendon which was subsequently retracted caudally by use of a self-retaining retractor (Weitlaner). The distended carpal canal sheath was observed to bulge into the surgical field. A centesis was performed by use of a $19 \mathrm{G}$ needle and subsequent analysis of the synovial fluid showed the total protein content to be $38 \mathrm{~g} / \mathrm{l}$ and the viscosity to be subjectively reduced. The tendon sheath was entered through a $5 \mathrm{~cm}$ incision and the excessive amount of synovial fluid removed by use of a standard suction device. The lesion could then be palpated as a smooth, bony protuberance projecting into the carpal canal sheath from the caudal aspect of the radius. A small osteotome and mallet were used to cleave the protuberance at its base. Following removal of the bony process, the caudal aspect of the radius was derided by use of a curette and rongeurs. The tendon sheath was lavaged with $1 / 2$ I of sterile isotonic polyionic fluid (Ringeracetat; Kabi Pharmacia AB, Sweden). The carpal canal sheath was closed by a continuous 2-0 polyglycolic acid suture (Dexon; Davis \& Geck, USA). Using a size 1 of the same suture material, the fascia was subsequently reapposed by interrupted sutures. The subcutaneous tissue was closed employing a continuous suture pattern also using the same suture material (size 2-0). Finally, the skin was closed by vertical mattress sutures of 1 polybutester (Novafil; Davis \& Geck, USA). A pressure bandage was applied to the distal antebrachial region.

\section{Gross pathologic and histologic examination}

The extirpated bony protuberance was mushroom-shaped and approximately $1 \mathrm{~cm}$ long with a diameter of $1 / 2-1 \mathrm{~cm}$. The top of the process was covered by a soft layer of tissue of what grossly appeared to be cartilage.

Histologically, the demineralized specimen consisted of a core of trabecular bone covered by a cap of hyaline carti- 
lage. The chondrocytes were arranged in columns, thus resembling those of a growth plate.

Based on the above findings, the clinical and radiographic diagnosis of osteochondroma-formation was confirmed.

\section{Postoperative course}

Flunixin meglumine (Finadyne; Scanvet, Denmark) was administered intravenously at a daily dosage of $0,5 \mathrm{mg} / \mathrm{kg}$ for 3 days. The pressure bandage was changed at postoperative days 5 and 8 , and in connection with the latter bandage change, control radiographs were taken of the left carpus showing complete removal of the osteochondroma. The horse was discharged from the hospital 12 days after surgery. The discharge instructions were 2 weeks of stall confinement, followed by 2 weeks of stall confinement combined with $2 \times 20$ minutes of hand walking each day, followed by free exercise in a pasture.

The horse was reexamined 8 weeks after surgery, at which time distention of the carpal canal sheath and pain on carpal flexion were not evident. At the walk, the horse was no longer lame whereas subtle lameness ( $<$ grade 1 out of 5 ) was observed at the trot.

The referring veterinarian reported by telephone 16 weeks postoperatively that the horse was not lame and that the carpal canal sheath was not swollen.

\section{Discussion}

The clinical symptoms displayed by the present case are consistent with those described in previous publications on osteochondroma formation in horses (Stahre et al. 1967; Lundvall and Jackson 1976; Stashak 1987; Honnas 1992). The clinical picture with swelling of the carpal canal sheath, painful response on flexion of the carpus and deep palpation of the caudomedial aspect of the carpus, and lameness is typical for the so-called 'carpal canal syndrome' (Stashak 1987). Different space-occupying lesions in the carpal canal sheath can cause this syndrome, osteochondroma formation at the distal radial metaphysis being one of them. Other space-occupying lesions to consider as clinical differential diagnoses are flexor tendon tendinitis, tenosynovitis, fracture of the accessory carpal bone, and desmitis of the accessory ligament of the superficial digital flexor tendon (Stashak 1987; Squire et al. 1992). The gross pathologic and histologic findings of a cartilage-covered bony protuberance located just proximal to the distal radial physis also correspond well with previous descriptions (Lee et al. 1979; Stashak 1987; Held et al. 1988; Honnas 1992). Osteochondroma formation occurs at only a single skeletal site, a fact which differentiates this condition from hereditary multiple exostoses. In the latter condition, which has been described in horses, multiple and often bilaterally symmetrical bony protuberances occur at several sites in the skeletal system (Shupe et al. 1979). Although the histologic appearance of the individual bony protuberances is similar to that of osteochondroma formation, the two conditions should be regarded as separate clinical entities. No hereditary background has been determined for osteochondroma formation at the distal radius (Stashak 1987).

In the present case, the osteochondroma was removed employing an incisional approach to the carpal canal sheath (Lundvall and Jackson 1976; Lee et al. 1979; Stashak 1987; Held et al. 1988; Honnas 1992). Recently, reports describing endoscopic approaches to the carpal canal sheath have been published (Squire et al. 1992; Southwood et al. 1997; Cauvin et al. 1997). Endoscopic surgery of the tendon sheath is performed using a $4 \mathrm{~mm}$ arthroscope inserted via a proximo-medial (Squire et al. 1992) or a proximo-lateral (Southwood et al. 1997) entry portal. A disto-lateral endoscopic approach also has been described (Cauvin et al. 1997). Reported advantages of the endoscopic technique when compared to the incisional approach include reduced tissue trauma and risk of infection, improved visualization within the tendon sheath, better cosmetic results, and shorter surgery and convalescence times (Squire et al. 1992; Southwood et al. 1997). However, the incisional technique used in the present case entailed a relatively short skin incision and careful tissue handling, and no untoward effects of the surgery were observed postoperatively. The convalescence regimen recommended for the present case also is comparable to that reported in previous publications.

In conclusion, the present report describes the typical clinical symptoms displayed in a case of osteochondroma formation at the caudal aspect of the distal metaphysis of the radius. Surgical removal of the osteochondroma was successful in alleviating the clinical symptoms. The gross pathologic and histologic appearance of the lesion confirmed the diagnosis of osteochondroma.

\section{References}

Cauvin, E. R. J., Schramme, M. C. and Munroe, G. A. (1997): Endoscopic examination of the carpal flexor tendon sheath in horses. Proceed. Sci. Meet. Europ. Coll. Vet. Surg. 6, 47-48

Held, J. P., Patton, C. S. and Shires, M. (1988): Solitary osteochondroma of the radius in three horses. J. Am. Vet. Med. Assoc. 193, 563-564

Honnas, C. M. (1992): Osteochondroma. In: Auer, J. A. (Ed): Equine surgery. W. B. Saunders Company, Philadelphia, 1038-1039

Jubb, K. V. F., Kennedy, P. C. and Palmer, N. (1985): Diseases of bones. In: Pathology of domestic animals. 3rd Ed. Academic Press Inc., Orlando, 83

Lee, H. A., Grant, B. D. and Gallina, A. M. (1979): Solitary osteochondroma in a horse: a case report. J. Equine Med. Surg. 3, 113-115

Lundvall, R. L. and Jackson, L. L. (1976): Periosteal new bone formation of the radius as a cause of lameness in two horses. J. Am. Vet. Med. Assoc. 168, 612-613

Shupe, J. L., Leone, N. C., Olson, A. E. and Gardner, E. J. (1979): Hereditary multiple exostoses: clinicopathologic features of a comparative study in horses and man. Am. J. Vet. Res. 40, 751-757

Southwood, L. L., Stashak, T. S., Fehr, J. E. and Ray, C. (1997): Lateral approach for endoscopic removal of solitary osteochondromas from the distal radial metaphysis in three horses. J. Am. Vet. Med. Assoc. 210, 1166-1168 
Squire, K. R. E, Adams, S. B., Widmer, W. R., Coatney, R. W. and Habig, C. (1992): Arthroscopic removal of a palmar radial osteochondroma causing lameness in a horse. J. Am. Vet. Med. Assoc. 201, 1216-1218

Stahre, L. and Tufvesson, G. (1967): Volar, supracarpal exostoses as causes of lameness in the horse. Nord. Vet. Med. 19, 356-361

Stashak, T. S. (1987): Osteochondroma formation at the distal radius (supracarpal exostoses). In: Stashak, T. S. (Ed): Adams' lameness in horses. 4th Ed. Lea \& Febiger, Philadelphia, 663-665

The author is grateful to Dr. H. Elvang Jensen, Dept. of Pathobiology, The Royal Veterinary and Agricultural University, for the histologic ex- amination of the extirpated specimen, and to Mr. B. R. Nilson, Dept. of Clinical Studies, The Royal Veterinary and Agricultural University, for the photographic reproduction of the radiograph.

Nicolai Jansson, DVM, PhD,

The Animal Hospital of Halland,

S-31050 Slöinge

Phone: (+46) 34640465

Fax: (+46) 34640191

E-mail:nick.jansson@hallandsdjursjukhus.se

\title{
European Society of Veterinary Surgery
}

\author{
19th Meeting in Vienna \\ September 17th-19th 1998 \\ Call for Papers
}

The 19th Meeting of the ESVS (European Society of Veterinary Surgery) is held at the University of Vienna between Thursday, September 17 and Saturday, September 19, 1998.

The scientific main theme as decided at the 18th Berlin Meeting is

\section{Teaching and Didactics in Veterinary Surgery}

covering the following points of main effort:

- Audivisual didactics in the field of veterinary surgery

- Presentation technics and systems

- Simple in vitro models in teaching

- Methods of knowledge control

- Documentation systems in diagnostic imaging

- Diagnosis orientated documentation systems

- Computerbased patient registration

- Related juridical problems in universities

On request of the non German speaking members of the ESVS, English was fixed as congress language. Please submit your paper or poster for the scientific program at latest before April 1st, 1998.

Please contact: Clinic of Orthopaedics in Ungulates Head: O. Univ. Prof. Dr. Christian Stanek

Tel.: ++43/1/25077/ext. 5301 (Secr. Gerda Zoerrer), Fax: ++43/1/25077/ext. 5590, email: Christian.Stanek@vu-wien.ac.at 